\title{
Performance of Nymphs and Adults of Piezodorus guildinii (Westwood) (Hemiptera: Pentatomidae) on Soybean Pods at Different Developmental Stages
}

\author{
Émerson D. M. Oliveira ${ }^{1}$ and Antônio R. Panizzi ${ }^{2 *}$ \\ ${ }^{1}$ Universidade Estadual de Londrina; Departamento de Agronomia; C. P. 6001; CEP 86051-970; Londrina - \\ Paraná - Brazil. ${ }^{2}$ Centro Nacional de Pesquisa de Soja - CNPSO; Empresa Brasileira de Pesquisa Agropecuária - \\ EMBRAPA; C. P. 231; CEP 86051-970; Londrina - Paraná - Brazil
}

\begin{abstract}
A study was conducted in the laboratory to test the suitability of soybean [Glycine max (L.) Merrill] pods at different phenological stages of development (R3-R8) on the performance of nymphs and adults of the small green stink bug Piezodorus guildinii (Westwood) (Hemiptera: Pentatomidae). Nymphs and adults showed better performance when fed on soybean pods during the pod-filling stage (R5-R6), compared to those fed on soybean pods at the remaining stages of development. When fed on soybean pods without seeds (R3-R4) no nymphs survived and no adults reproduced.
\end{abstract}

Key words: Heteroptera, Pentatomidae, stink bug, Glycine max, soybean pod phenology, biology

\section{INTRODUCTION}

Piezodorus guildinii (Westwood) is a neotropical stink bug, and an important pest of soybean [Glycine $\max (\mathrm{L}$.$) Merrill] in South America$ (Panizzi and Slansky, 1985a). Much information is available on the impact of this stink bug to soybean seed yield and quality, and on different aspects of its biology, including cultivated and wild host plants (Panizzi and Smith, 1977; Panizzi and Slansky, 1985b; Panizzi, 1992).

$P$. guildinii is adapted to explore soybean as a nutritional resource throughout the production areas of Brazil, having a wide distribution from the southern most state of Rio Grande do Sul (latitude around $30^{\circ} \mathrm{S}$ ) up to Maranhão state in the northeastern areas of the country (latitudes around $10^{\circ}$
S). All over these areas this bug has been observed to colonize soybean and wild hosts, such as legumes of the genus Indigofera (Panizzi and Slansky, 1985a).

Several studies on the biology of the nymphs and adults of $P$. guildinii have been conducted (references in Panizzi, 1997), and results obtained in the laboratory indicated high mortality and reduced longevity. In order to explain the reason why the insect was abundant in the field on soybean, but did not succeed when raised on this plant in the laboratory, this work was conducted with the following objectives: compare the development of nymphs of $P$. guildinii on soybean pods at different stages of development (R3 = pod set to R8 = pod maturity) (Fehr et al., 1971); and evaluate the adult performance of

* Author for correspondence 
$P$. guildinii on soybean pods at these different developmental stages.

\section{MATERIAL AND METHODS}

During December 1998, P. guildinii adults were collected on Indigofera spp. and soybean, at the Experimental Field Station of Embrapa Soybean in Londrina, northern Paraná. The insects were taken to the laboratory and placed in plastic box $(11.0 \mathrm{x}$ $11.0 \times 3.5 \mathrm{~cm}$ ) with filter paper and moistened cotton and covered with a lid, and then placed in an environmental chamber maintained at $25 \pm 1{ }^{\circ} \mathrm{C}$, $60 \pm 10 \%$ RH, 14:10 (L:D) $\mathrm{h}$ photoperiod, containing 'Paraná' soybean pods in R6 (full seed) and Indigofera truxilliensis H.B.K. pods to obtain egg masses.

Laboratory Study (Nymphs): The study with nymphs was conducted during January to April 1999. Eggs were placed in plastic dishes $(9.0 \times 1.5$ $\mathrm{cm}$ ) lined with moistened filter paper, and then placed in an environmental chamber. On the 1st day of the 2nd instar (1st instar do not feed) nymphs were placed individually in Petri dishes, with soybean pods cv. 'Paraná' at different phenological stages of development (R3 - R8)

(Fig. 1).
Daily observations were made on moulting and mortality, and food was replaced every $2 \mathrm{~d}$. Nymphal development time and percentage mortality were calculated. Fresh body weight at adult emergence was taken using an electronic balance. Treatments (nymphs feeding on soybean pods R3 - R8) were set at random. Data obtained were analyzed statistically using the SANEST program (Zonta and Machado, 1992), and the means compared using the Tukey test $(\mathrm{P}<0.05)$.

Laboratory Study (Adults): The study with adults was conducted during February to July 1999. Twenty couples of $P$. guildinii were used for each treatment, i.e., different phenological stages of development of soybean pods plus mature seeds, in a total of 140 pairs. Each adult was weighted at the $8^{\text {th }}$ and $15^{\text {th }}$ day of age. The egg masses deposited by females were removed and placed individually in Petri dishes. The parameters measured in this study were: the longevity of adults; the percentage of females that oviposited, the age at the first oviposition, the number of egg masses and eggs per female, and the eggs viability. Data obtained were analyzed statistically as described for the study with nymphs.

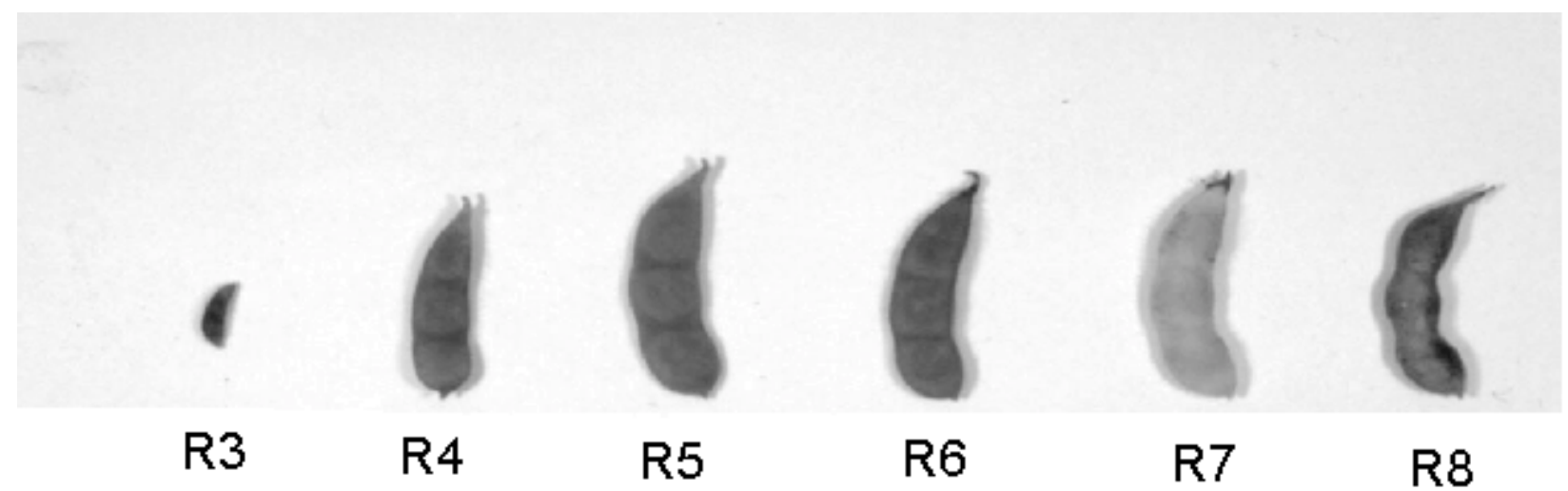

Figure 1 - Soybean pods at different phenological stages of development (R3 to R8). R3 = pod set; R4 = full pod developed; R5 = pod begining to fill seed; R6 = pod with seeds completely filled; R7 = pods begining to mature; R8 = pods completely mature (Fehr et al., 1971).

\section{RESULTS AND DISCUSSION}

Laboratory Study (Nymphs): Differences on the nymphal development time, survivorship and body weight at adult emergence of $P$. guildinii were observed with different food sources utilized. In general, nymphs took longer time to complete development on mature seeds (R8SM) than on 
pods with imature seeds (R5-R6) or on pods beginning maturity (R7) (Table 1).

On soybean pods without seeds, initiating development (R3) or fully developed (R4), nymphs completed development up to the $2^{\text {nd }}$ or to the $4^{\text {th }}$ stadia only (Table 1).

Nymph mortality was $100 \%$ on soybean pods with no seeds (R3-R4) and on mature soybean pods (R8), indicating that $P$. guildinii nymphs needed to feed on immature seeds (Fig. 2).

They survived in low numbers ( $83.3 \%$ mortality) on exposed mature seeds. Aparently, mature pods with dry pilosity prevented nymphs from normal feeding causing all them to perish. Mature seeds, however, allowed some nymphs to complete development, despite their low water content and possible lack of nutrients or accumulation of toxic allelochemicals.

Usually, $P$. guildinii nymphs have high mortality in any food. Even on the preferred foods such as pods of the legumes of the genus Indigofera, nymph mortality was high (higher than $50 \%$, except on $I$. endecaphylla Jacq. $=12 \%$; Panizzi, 1992).
Therefore, the lowest mortality observed in our study, i.e., $47.6 \%$ on soybean pods at R6, is considered a good value. It is not known if these usually high nymph mortality values observed in the laboratory also in the field. Perhaps, high nymph mortality is a characteristic of this species, allowing only the most adaptive individuals to survive and reach the adult stage.

Fresh body weight at adult emergence was greater or tended to be greater on soybean pods with immature seeds (R5 to R7) than on mature seeds (R8 MS) (Table 2). In general, females were significantly heavier than males. These data on body weight are in agreement with the other nymphal developmental traits studied, which indicated also immature pods as the most suitable food.

Laboratory Study (Adults): Similar to the results obtained with nymphs, adults of $P$. guildinii performed better when fed on immature soybean pods with seeds (R5-R6) than when fed on pods without seeds (R3-R4) or mature (R8).

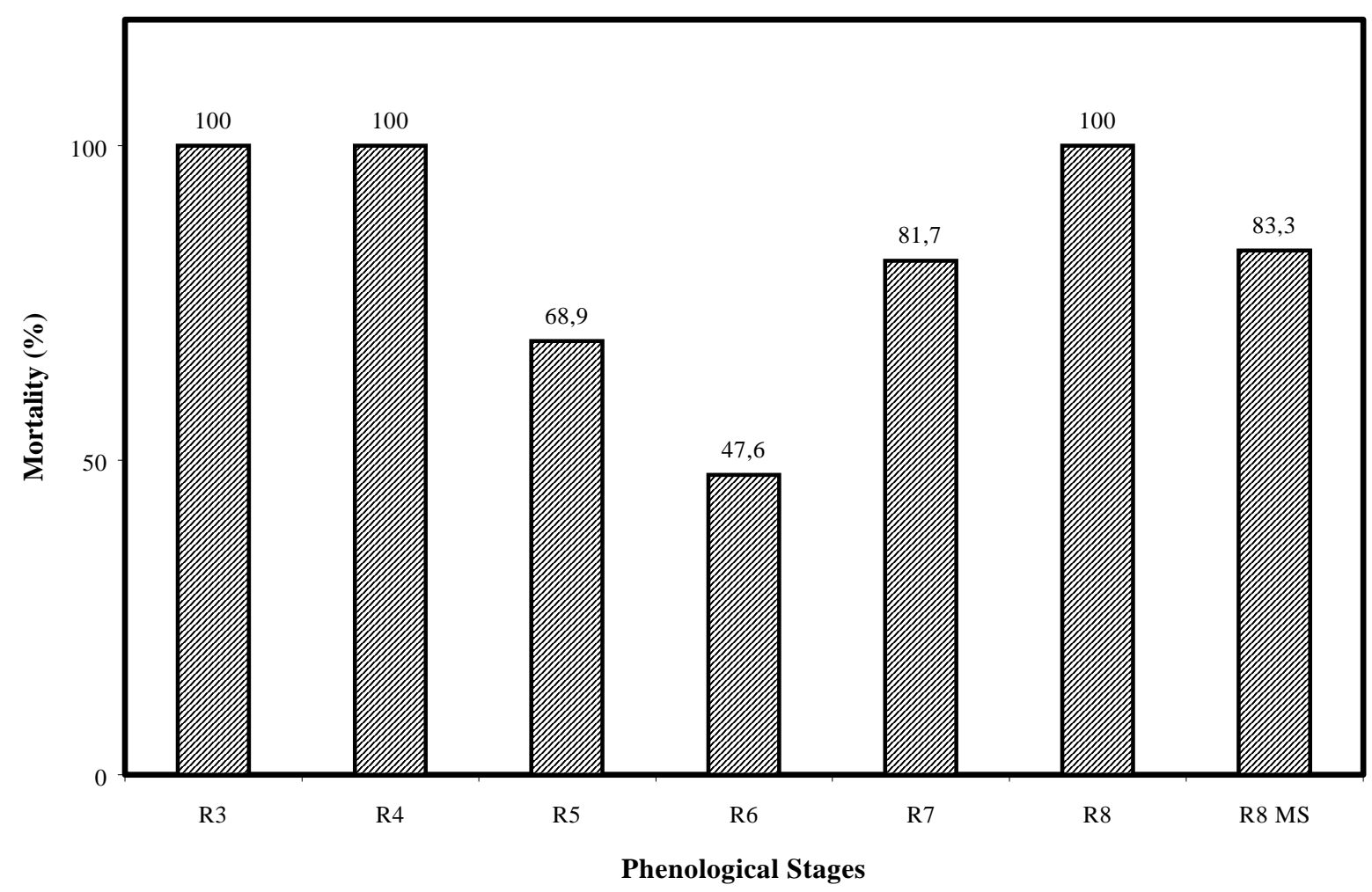

Figure 2 - Nymphal mortality (\%) of Piezodorus guildinii feeding on soybean pods at different phenological stages of development (R3 - R8) in the laboratory. R3 = pod set; R4 = full pod; R5 = seed development; R6 = full seed; R7 = beginning maturity; R8 = full maturity; R8 MS = mature seed. 
On maturing pods (R7) the performance was intermediate.

With regard to adult longevity (mean of females and males), $P$. guildinii lived for over 70 days when fed on soybean pods at R5 (Table 3). On soybean pods at R6 this value was ca. 50 days; on R7 and R8 it was ca. 43 days; and on mature seeds (R8 MS) or on pods without seeds (R3 and R4) mean longevity decreased to less than 30 days. The reproductive performance showed similar tendency, with soybean pods at R5 and R6 being the most suitable foods. On these pods, ca. $50 \%$ of the females oviposited, while on maturing (R7) or mature (R8) pods, ca. $20 \%$ of the females laid eggs (Table 4). On mature seeds (R8 MS), only 5 $\%$ of the females oviposited, and on soybean pods without seeds (R3 and R4), none of the females tested oviposited.

These results indicate that feeding on immature pods (R5-R6) was essential for ovary development and egg production, and that females have their fecundity drastically reduced on maturing (R7) or mature soybean seeds (R8 MS). For another major pentatomids pest of soybean, Nezara viridula (L.), however, this is not true. Females show better reproductive performance when fed on maturing pods (R7) (Panizzi and Alves, 1993).

The time for first oviposition was shorter (22 days) for females feeding on soybean pods at R6, indicating faster ovary development on this food. On the remaing pod developemtnal stages this value varied from 32 to 63 days (Table 4). Fecundity measured as the number of egg masses and total number of eggs produced by each female also indicated soybean pods at R5 and R6 as the most suitable foods (Table 4). Despite no statistical differences in some values due to data variability and small sample size ( $n$ in some cases < 5), clearly females showed greater egg production when fed on immature soybean pods. Egg hatchability was also variable, but, in general, followed the same trend as observed to egg production.

Results of these studies demonstrated that nymph and adult $P$. guildinii did not develop well when fed on soybean pods at stages R3, R4 and R8 and showed intermediate performance on pods at the stage R7. Pods in the stages R5 and R6 were, in general, more suitable for nymphs and adults.

Table 1 - Mean developmental time ( \pm SEM) of Piezodorus guildinii feeding on soybean pods at different phenological stages of development (R3 - R8), in the laboratory (number of nymphs in parentheses; initial number $=40$ ).

\begin{tabular}{|c|c|c|c|c|c|c|}
\hline \multirow{2}{*}{ Stages } & \multicolumn{4}{|c|}{ Stadium duration ${ }^{1}$,day } & \multicolumn{2}{|c|}{ Total developmental time ${ }^{1}$, day } \\
\hline & $2^{\circ}$ & $3^{\circ}$ & $4^{\circ}$ & $5^{\circ}$ & Female & Male \\
\hline R3 & $\begin{array}{c}4.0 \pm 0.00 \\
(1)^{2}\end{array}$ & - & - & - & - & - \\
\hline $\mathrm{R} 4$ & $\begin{array}{c}6.6 \pm 0.48 \mathrm{a} \\
(24)\end{array}$ & $\begin{array}{c}7.7 \pm 0.96 \mathrm{a} \\
(11)\end{array}$ & $\begin{array}{c}8.5 \pm 1.19 \mathrm{a} \\
\text { (4) }\end{array}$ & - & - & - \\
\hline $\mathrm{R} 5$ & $\begin{array}{c}5.4 \pm 0.33 \text { a } \\
(23)\end{array}$ & $\begin{array}{c}4.4 \pm 0.25 \mathrm{~b} \\
(19)\end{array}$ & $\begin{array}{c}3.8 \pm 0.20 \mathrm{c} \\
(18)\end{array}$ & $\begin{array}{c}6.5 \pm 0.12 b \\
(18)\end{array}$ & $\begin{array}{c}19.9 \pm 0.50 \mathrm{~b} \\
(10)\end{array}$ & $\begin{array}{c}19.9 \pm 0.85 \mathrm{a} \\
(8)\end{array}$ \\
\hline R6 & $\begin{array}{c}6.0 \pm 0.35 \mathrm{a} \\
(35)\end{array}$ & $\begin{array}{c}4.3 \pm 0.18 \mathrm{~b} \\
(32)\end{array}$ & $\begin{array}{c}3.9 \pm 0.16 \mathrm{c} \\
(32)\end{array}$ & $\begin{array}{c}6.7 \pm 0.10 b \\
(31)\end{array}$ & $\begin{array}{c}20.0 \pm 0.44 \mathrm{~b} \\
(14)\end{array}$ & $\begin{array}{c}21.6 \pm 0.89 \mathrm{a} \\
(17)\end{array}$ \\
\hline R7 & $\begin{array}{c}5.4 \pm 0.27 \mathrm{a} \\
(17)\end{array}$ & $\begin{array}{c}4.3 \pm 0.19 \mathrm{~b} \\
(14)\end{array}$ & $\begin{array}{c}3.7 \pm 0.31 \mathrm{c} \\
(12)\end{array}$ & $\begin{array}{c}6.0 \pm 0.62 b \\
(11)\end{array}$ & $\begin{array}{c}20.4 \pm 0.75 \mathrm{~b} \\
(5)\end{array}$ & $\begin{array}{c}20.0 \pm 1.00 \mathrm{a} \\
(6)\end{array}$ \\
\hline R8 MS & $\begin{array}{c}6.1 \pm 0.31 \mathrm{a} \\
(22)\end{array}$ & $\begin{array}{c}4.5 \pm 0.17 \mathrm{~b} \\
(20)\end{array}$ & $\begin{array}{c}5.3 \pm 0.30 \mathrm{~b} \\
(15)\end{array}$ & $\begin{array}{c}8.1 \pm 0.71 \mathrm{a} \\
(10)\end{array}$ & $\begin{array}{c}24.2 \pm 1.38 \mathrm{a} \\
(6)\end{array}$ & $\begin{array}{c}23.8 \pm 1.11 \mathrm{a} \\
(4)\end{array}$ \\
\hline
\end{tabular}


Table 2 - Fresh body weight $(\mathrm{mg})(\mathrm{X} \pm \mathrm{SE})$ of females and males Piezodorus guildinii feeding on soybean pods at different phenological stages of development (R5 - R8), in the laboratory (number of nymphs in parentheses)

\begin{tabular}{ccccc}
\hline \multirow{2}{*}{ Adults } & \multicolumn{4}{c}{ Phenological Stages $^{1}$} \\
\cline { 2 - 5 } & $\mathrm{R} 5$ & $\mathrm{R} 6$ & $\mathrm{R} 7$ & $\mathrm{R} 8 \mathrm{MS}$ \\
\hline Female & $59.8 \pm 2.64$ a A & $62.4 \pm 2.48$ a A & $59.6 \pm 3.70$ a AB & $46.2 \pm 3.29$ a B \\
& $(10)$ & $(14)$ & $(5)$ & $(6)$ \\
Male & $47.9 \pm 2.68 \mathrm{~b} \mathrm{~A}$ & $50.8 \pm 1.52 \mathrm{~b} \mathrm{~A}$ & $51.8 \pm 2.15 \mathrm{a} \mathrm{A}$ & $43.0 \pm 2.42 \mathrm{a} A$
\end{tabular}

(8)

(17)

(6)

(4)

${ }^{1}$ Means followed by the same lower case letter in each column and same upper case letter in each row, are not significantly different $(\mathrm{P}<0.05$, Tukey's multiple range test). $\mathrm{R} 5$ = beginning seed; $\mathrm{R} 6=$ full seed; $\mathrm{R} 7$ = beginning maturity; $\mathrm{R} 8 \mathrm{MS}=$ mature seed.

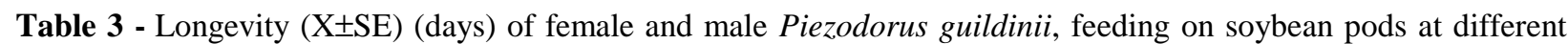
phenological stages of development $(\mathrm{R} 3-\mathrm{R} 8)$, in the laboratory $(\mathrm{n}=20)$

\begin{tabular}{|c|c|c|}
\hline \multirow[b]{2}{*}{ Stages } & \multicolumn{2}{|c|}{ Longevity $^{1}$} \\
\hline & $\begin{array}{c}\text { Male } \\
(\mathrm{X} \pm \mathrm{EP})\end{array}$ & $\begin{array}{c}\text { Female } \\
(\mathrm{X} \pm \mathrm{EP})\end{array}$ \\
\hline R3 & $15.6 \pm 1.15 \quad b \quad$ B & $20.7 \pm 1.57 \quad b \quad A$ \\
\hline $\mathrm{R} 4$ & $22.2 \pm 3.60 \quad \mathrm{c} \quad \mathrm{A}$ & $32.3 \pm 6.40 \quad \mathrm{~b} \quad \mathrm{~A}$ \\
\hline R5 & $67.0 \pm 7.52$ a $\mathrm{A}$ & $79.1 \pm 8.40 \quad \mathrm{a} \quad \mathrm{A}$ \\
\hline R6 & $54.8 \pm 10.00 \mathrm{ab} \mathrm{A}$ & $47.8 \pm 8.46 \quad \mathrm{ab} \mathrm{A}$ \\
\hline R7 & $43.4 \pm 9.14$ abc A & $40.6 \pm 9.16 \quad \mathrm{~b} \quad \mathrm{~A}$ \\
\hline R8 & $39.8 \pm 9.79$ abc A & $47.9 \pm 11.06 \mathrm{ab} \mathrm{A}$ \\
\hline R8 MS & $24.6 \pm 6.80$ bc $A$ & $30.1 \pm 8.72 \quad$ b $\quad A$ \\
\hline
\end{tabular}

${ }^{1}$ Means followed by the same lower case letter in each column and same upper case letter in each row, are not significantly different $(\mathrm{P}<0.05$, Tukey's multiple range test $)$ R3 = beginning pod; $\mathrm{R} 4=$ full pod; $\mathrm{R} 5$ = beginning seed; $\mathrm{R} 6=$ full seed; $\mathrm{R} 7=$ beginning maturity; $\mathrm{R} 8$ = full maturity; $\mathrm{R} 8 ; \mathrm{MS}$ = mature seed.

Table 4 - Reproductive performance of Piezodorus guildinii females feeding on soybean pods at different phenological stages of development (R3-R8), in the laboratory (number of females in parentheses)

\begin{tabular}{|c|c|c|c|c|c|c|}
\hline \multirow[b]{2}{*}{ Stages } & \multirow[b]{2}{*}{$\begin{array}{l}\% \text { females } \\
\text { ovipositing }\end{array}$} & \multirow[b]{2}{*}{$\begin{array}{l}\text { Female age (days) } \\
\text { at. } 1^{\text {st }} \text { oviposition } \\
\\
(\mathrm{X} \pm \mathrm{SE})\end{array}$} & \multicolumn{2}{|c|}{ Number/female ${ }^{2}$} & \multirow{2}{*}{\multicolumn{2}{|c|}{$\begin{array}{c}\text { Egg hatchability }(\%)^{1} \\
\qquad(\mathrm{X} \pm \mathrm{SE})\end{array}$}} \\
\hline & & & $\begin{array}{c}\text { Egg Masses }^{1} \\
(\mathrm{X} \pm \mathrm{SE})\end{array}$ & $\begin{array}{c}\text { Eggs }^{1} \\
(\mathrm{X} \pm \mathrm{SE})\end{array}$ & & \\
\hline R3 & 0 & - & - & - & - & \\
\hline $\mathrm{R} 4$ & 0 & - & - & - & - & \\
\hline R5 & 50 & $\begin{array}{c}59.9 \pm 7.75 \text { a } \\
(10)\end{array}$ & $\begin{array}{c}9.1 \pm 1.79 \mathrm{a} \\
(10)\end{array}$ & $\begin{array}{c}164.6 \pm 35.83 \mathrm{a} \\
(10)\end{array}$ & $\begin{array}{c}75.6 \pm 9.42 \\
(10)\end{array}$ & $\mathrm{a}$ \\
\hline R6 & 45 & $\begin{array}{c}22.0 \pm 6.96 \quad b \\
(9)\end{array}$ & $\begin{array}{c}9.0 \pm 3.82 \mathrm{a} \\
(9)\end{array}$ & $\begin{array}{c}120.9 \pm 34.03 \mathrm{a} \\
(9)\end{array}$ & $\begin{array}{c}59.4 \pm 14.82 \\
(9)\end{array}$ & $\mathrm{a}$ \\
\hline R7 & 20 & $\begin{array}{c}63.5 \pm 12.39 \mathrm{a} \\
(4)\end{array}$ & $\begin{array}{c}5.8 \pm 2.25 \mathrm{a} \\
(4)\end{array}$ & $\begin{array}{c}103.5 \pm 39.66 \mathrm{a} \\
(4)\end{array}$ & $\begin{array}{c}84.4 \pm 4.89 \\
(4)\end{array}$ & $\mathrm{a}$ \\
\hline $\mathrm{R} 8$ & 15 & $\begin{array}{c}32.7 \pm 17.70 \quad \mathrm{ab} \\
(3)\end{array}$ & $\begin{array}{c}2.0 \pm 0.00 \mathrm{a} \\
(3)\end{array}$ & $\begin{array}{c}28.7 \pm 3.84 \quad b \\
(3)\end{array}$ & $\begin{array}{c}29.2 \pm 29.2 \\
(3)\end{array}$ & $\mathrm{a}$ \\
\hline R8 MS & 5 & $\begin{array}{c}56.0 \pm 0.00 \\
(1)^{2}\end{array}$ & $\begin{array}{c}5.0 \pm 0.00 \\
(1)^{2}\end{array}$ & $\begin{array}{c}113.0 \pm 0.00 \\
(1)^{2}\end{array}$ & $\begin{array}{c}77.9 \pm 0.00 \\
(1)^{2}\end{array}$ & \\
\hline
\end{tabular}




\section{ACKNOWLEDGMENTS}

We thank Flávio Moscardi and Norman Neumaier for revising an early draft of the manuscript. This study was sponsored by Empresa Brasileira de Pesquisa Agropecuária (EMBRAPA), Centro Nacional de Pesquisa de Soja (Embrapa Soja). This is publication number 10/2001 of Embrapa Soja.

\section{RESUMO}

Estudos foram conduzidos em laboratório para testar a adequabilidade de vagens de soja [Glycine $\max (\mathrm{L}$.$) Merrill] em diferentes fases fenológicas$ (R3-R8) na performance de ninfas e adultos do percevejo verde pequeno Piezodorus guildinii (Westwood) (Hemi-ptera: Pentatomidae). Tanto ninfas como adultos mostraram uma melhor performance quando se alimentaram das vagens de soja na fase de enchimento de grãos (R5-R6), comparado com aqueles que se alimentaram de vagens de soja nas demais fases de desenvolvimento. Em vagens sem grãos (R3-R4) nenhuma ninfa sobreviveu e não houve reprodução.

\section{REFERENCES}

Fehr, W. R.; Caviness, C. E.; Burmood, D. T. and Pennington, J. S. (1971), Stage of development descriptions for soybeans, Glycine $\max (\mathrm{L}$.$) Merrill.$ Crop Science, 11 : (6), 929-931.

Panizzi, A. R. (1992), Performance of Piezodorus guildinii on four species of Indigofera legumes. Entomologia Experimentalis et Applicata, 63 : (3), 221-228.

Panizzi, A. R. (1997), Wild hosts of pentatomids: Ecological significance and role in their pest status on crops. Annual Review of Entomology, 42, 99-122.

Panizzi, A. R. and Alves, R. M. L. (1993), Performance of nymphs and adults of the southern green stink bug (Heteroptera: Pentatomidae) exposed to soybean pods at different phenological stages of development. Journal of Economic Entomology, 86, (4), 10881093.

Panizzi, A. R. and Slansky, F. (1985a), Review of phytophagous pentatomids (Hemiptera: Pentatomidae) associated with soybean in the Americas. Florida Entomologist, 68 : (1), 184-214.
Panizzi, A. R. and Slansky, F. (1985b), Legume host impact on performance of adult Piezodorus guildinii (Westwood) (Hemiptera: Pentatomidae). Environmental Entomology, 14 : (3), 237-242.

Panizzi, A. R. and Smith, J. G. (1977), Biology of Piezodorus guildinii: oviposition, development time, adult sex ratio, and longevity. Annals of the Entomological Society of America, 70 : (1), 35-39.

Zonta, E. P and Machado, A. A. (1992), SANEST Sistema de Análise Estatística para Microcomputadores. Universidade Federal de Pelotas, Pelotas, RS. 